\title{
THE DEIFICATION OF THE "LYRE" IN ANCIENT UGARIT*
}

\author{
Matahisa KoITABASHI**
}

We find that the Ugaritic term $k n r$ "lyre"(1) is deified in two Ugaritic texts. One is in the Ugaritic pantheon list (KTU 1. 47: 32; KTU 1. 118: 31), (2) the other is in the offering text ( $K T U$ 1. 148: 9). In the pantheistic world everything can be conceived as gods. (3) Therefore it is no wonder that musical instruments are deified along with other objects in Ugarit. But why lyres? Beside knr "lyre", we have several Ugaritic terms for musical instruments such as $m s \underline{l t m}$ "cymbals", $t p$ "hand-drum" and $t l b$ "pipe". It might be possible that $k n r$ "lyre" in the Ugaritic pantheon list and in the offering text represents other musical instruments. But in that case it remains problematic why the "lyre" should occupy a special position in the Ugaritic rituals. Is there any motive for the deification of the lyre in ancient Ugarit?

A Sumerian DINGIR-sign is sometimes attached to musical instruments used in rituals of ancient Babylonia. In the ritual for covering a kettledrum used in rituals, offerings are set to the god kettledrum (dilissu) along with other gods (AO 6479: III: 17).(4) It is possible that after this ritual had completed unmistakably and perfectly, the newly covered kettledrum was purified and so deified. (5) In the Old Babylonian god lists, $\mathrm{AN}=A$ Anum, the term balag "a musical instrument"(6) and lum. ha are equated with Ea.

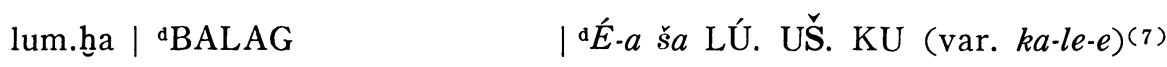

Lumba | The BALAG-instrument | Ea of Kal $\hat{\text {-priest }}$

Ea is associated with the term balag in this list. This list indicates that

* I gratefuly thank Professor David T. Tsumura for his constructive criticism and suggestions for this article.

All texts in this article are cited with the abbreviations used in the Chicago Assyrian Dictionary.

** Teacher, Tokyo Metropolitan Kiyose-Higashi High School 
the god Ea, who is considered the god of balag-instruments, appears to be the patron deity of $k a l \hat{u}$-priests. Among the Egyptian pictures we can find the falcon-headed symbol of god Horus attached to a harp or lute. (8) This symbol might be associated with the deification of a harp and a lute and might mean that the god Horus is the patron deity of string-instrumentalists such as harpists or lutenists. Then what kind of motive can we see in the "deified lyre" of Ugarit?

We can see that the last part of the Ugaritic pantheon list ( $K T U$ 1. 47: 31-32; 1. 118: 30-31; RS 20. 24: 30-31) contains cultic equipments (utht, knr). Several cultic equipments are also deified in the other texts from Ugarit. For instance 11 is zannaru "lyre" in RS 26. 142:6 is preceded by a cultic vase (11 DUGBUR ZI. NÍG. DIN).(9) The god censor (aǧršh -n-d=ahrušhi-ni-da) and the god vase (hbršh-n-d=hubrušhi-ni-da) are mentioned among the Hurrian pantheon from Ugarit.(10)

In the Ugaritic text listing offerings to gods ( $K T U$ 1. 148: 9), the god lyre is found along with most of gods which are listed in the Ugaritic pantheon list. This offering list reflects that offerings were given to the god lyre in a certain ritual. It is interesting to note in this connection that in the offering text from Umma the term balag appears with a DINGIR-sign. (11) In the Sumerian offering texts from the time of Lugalanda and Urkagina of Lagash, sacrifices were brought to the musical instrument "balag" by itself or together with other deities and cultic equipments. (12) As a cultic equipment in the ritual of Teššb and Hepat, the vase (hubrušh in) was given a sacrifice. (13)

Therefore, cultic equipments including musical instruments were deified and were sacrificed to in the ancient Near Eastern religious practice. Cultic equipments such as a vase, a censor and musical instruments ensured the comfort of the deity. And these equipments were often considered pure and treated as if they had divine powers. Probably it was thought that a musical instrument, a lyre, had a divine power in Ugaritic rituals as those cultic equipments in the ancient Near East. It is possible to say that lyres had an important function in some royal rituals or city-cults of Ugarit. (14) But in these cases it remains problematic why "lyres" should have a special divine power in Ugaritic rituals. I present here one probable explanation about why the "lyre" should occupy a special position in Ugaritic rituals.

In the Mesopotamian context, rituals or objects used in rituals are explained in terms of theology and mythology. In a Babylonian list (CBS 
6060 and dupls.) trees, plants, animals, substances, or articles are equated with deities. Most of these had a use in rituals or in the making of objects used in rituals. Among them we can find the several musical instruments (CBS 6060: 44, 45).

urudu. níg. kalag. ga dnin-šar $u$ dnergal (u. gur)

kuš. $\mathrm{gu}_{4}$. gal dindagar (NINDÁ $\times$ GUD)

The cymbals :Ninšar and Nergal

The drum :Indagar ${ }^{(15)}$

A Babylonian text (BM 34035 11. 13-23) narrates the ritual for curing a sick man and it equates individual items of equipment with deities and gives partial explanations of how the cure was achieved. Among the individual items of equipment the same musical instruments as in the list (CBS 6060 and dupls.) are mentioned.

kuš-gu,-gal-úu urudu-níg-kala-ga ša ina rēš 'úmarṣi i-be-en-n[i]

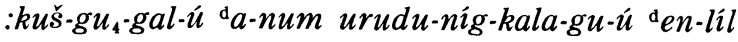

The drum and cymbals which are resplendent at the head of the sick man. :The drum is Anu. The cymbals are Enlil.(16)

We might observe in these Babylonian explanatory works that the drum and cymbals are used as divine representation. It is no wonder that the drum and cymbals were treated as if they had divine powers in the ritual for curing a sick man because the sound of drum and cymbals is thought to be effective for driving out the evil spirit of sickness.

Although a lyre is different from a drum and cymbals in a style of playing, the Israelite lyre is similar in function to the drum and cymbals of Babylonia. We could assume that the Israelite lyres were treated as if they had a special divine power in some exorcistic rituals just as the drum and cymbals of Babylonia. It is well known that David cured Saul's melancholy by playing a kinnôr "lyre". When David played his lyre, the evil spirit departed from Saul and Saul felt beter (I Sam. 16:23). We could assume that this supernatural effect of the lyre was believed in among the 
ancient Israelite people because the servants of Saul advised the king to find a good-skilled lyre player in order to drive out the evil spirit of the God (I Sam. 16: 15-18). This lyre's magic practice of manipulating gods' feeling might be widespread in ancient Canaan and might be related to the deification of the lyre in ancient Ugarit.

It is interesting that the harp (balag) whose name is Ushumgalkalam$\mathrm{ma}$ is called "counselor" in the Cylinder of Gudea (The Cylinders of Gudea A vi $26-27)^{(17)}$. Jacobsen explains why the temple harp is considered to be the counselor and is deified in the following way. "Harp music was effective in calming emotional turmoil and so made rational action possible. Temple harps were therefore considered the counselors of the deities to which they belonged, and they were often deified".(18) Although the construction of harps is not the same as that of lyres, they are of one accord in that they have several strings and resonant boxes. Even though there is a difference in volume of sound between harps and lyres, the difference of tone between two musical instruments may not be very large. In the Eblaite bilingual text which was recently published, the term gi-na-rum is listed with balag. (19) This text indicates that the semitic $k n r$ is thought to be interchangeable with the Sumerian balag in some cases.

We see that a drum and cymbals were used in the exorcistic ritual for curing a sick man in ancient Babylonia. It is possible that string instruments were used in some magic or some ritual for manipulating the gods' feeling in the ancient Near East. It thus might be said that the lyre's magic practice of manipulating gods' feeling is a motive for its deification in ancient Ugarit.

\section{Notes}

(1) The same root is widespread in the ancient Near East and Greece. Cf. C. H. Gordon, Ugaritic Textbook (Roma: Pontificium Institutum Biblicum, 1965; 1967), §19. 1274.

(2) The Akkadian term kinnāru which is equivalent to the Ugaritic $k n r$ is also deified in the Akkadian pantheon list from Ugarit (RS 20. $24: 31$ ).

(3) For instance we can find many deities in a feast of Baal (KTU $14:$ VI : 47-54). According to this Ugaritic passage, ram (kr), ewe (hprt), bull (alp), cow (arht), throne (kht), chair (ksu), jar (rhbt) and jug (dkrt) are conceived as gods. Cf. C. H. Gordon, "Poetic Legends and Myths from Ugarit," Berytus 25 (1977), p. 99.

(4) F. Thureau-Dangin, Ritueles accadiens (Paris: Ernest Leroux, 1921), pp. 16-17.

(5) Dr. Alasdair Livingstone orally suggested this interpretation to me (March 22 1992). 
(6) The word balag was a musical instrument, originally a harp. But later it might be related to a kind of drum because balag occurs among other words which designate percussion instruments, and the "skin" of the balaggu is mentioned. Cf. $C A D \mathrm{~B}$, pp. 38-39.

(7) CT $2548: 11$, var. from CT $2443: 120$; cf. $C A D, \mathrm{~K}$, p. 92.

(8) Hans Hickmann, Musikgeschichte in Bildern: Ägypten Band II Lieferung 1 (Leipzig: VEB Deutscher Verlag für Musik Leipzig, 1961), pp. 83, 101, 129.

(9) Ugaritica 5 (1968), p. 321.

(10) E. Laroche, "Notes sur le Panthéon Hourrite de Ras Shamra," Journal of American Oriental Studies 88 (1968), p. 149; E. Laroche, "Le 《Panthéon》Hourrite de Ras Shamra", Ugaritica 5 (1968), p. 526.

(11) TEO 5672115: III 11. N. Schneider, “Das Drehem=und Djohaarchiv," Orientalia (OS) 8 (1924), p. 31 .

(12) Henrike Hartman, Die Musik der sumerischen Kultur (Frankfurt am Main: Bildstelle der J. W. Goethe-Universität, 1960), p. 53.

(13) KUB 27, 13122. G. Wilhelm, "Hुubrušhi," in Reallexikon der Assyriologie und Vorderasiatischen Archäologie 4 (Berlin \& New York: Walter de Gruyter, 1972-1975), p. 478 .

(14) One of the possible opinions was offered by Dr. Healy. He states that some very minor divinities in the last section of the Akkadian pantheon list from Ugarit may be specifically linked with the particular cult-centre of which the whole list is a reflection. J. F. Healey, "The Akkadian 'Pantheon' List from Ugarit", Studi Epigrafici e Linguistici 2 (1985), p. 121.

(15) Alasdair Livingstone, Mystical and Mythological Explanatory Works of Assyrian and Babylonian Scholars (Oxford: Clarendon Press, 1986), pp. 178-179.

(16) Ibid, pp. 172-173.

(17) "Ushumgalkalamma, his (well)-beloved harp, the renowned psaltery his counselor" T. Jacobsen, The Harp that Once... (New Haven and London: Yale University Press, 1987), p. 396; F. Thureau-Dangin, Les Cylindres de Goudéa: Première Partie Transcription et Traduction (Paris: Ernest Leroux, 1905), p. 16. Thureau-Dangin translates here the term balag as "lyre".

(18) Jacobsen, op. cit., p. 396 n. 33.

(19) G. Pettinato, Testi Lessical Bilingui della Biblioteca L2769 Pt. 1 (Naples: Istituto Universtario Orientale di Napoli, 1982), p. 264 no 572. 